\title{
THE ROLE OF BIOMARKERS IN THE ASSESSMENT OF FRAGILITY SYNDROME IN THE ELDERLY
}

\author{
Ana Popa ${ }^{1}$, Anatolie Negară ${ }^{1}$, Gabriela Șoric ${ }^{1}$, Ion Sîrbu², Ana Popescu \\ ${ }^{1}$ Laboratory of Geriatrics and Gerontology, State University of Medicine and Pharmacy \\ "Nicolae Testemițanu", Chișinău, the Republic of Moldova \\ ${ }^{2}$ Internal Medicine Department: Clinical Syntheses Department, State University of Medicine \\ and Pharmacy "Nicolae Testemițanu", Chișinău, the Republic of Moldova \\ Corresponding author: \\ Ana Popa,popaana2805@gmail.com
}

\begin{abstract}
Fragility is an important concept in geriatric medicine, and the study of its etiology has become a fundamental aspiration of many researchers in the field of aging ${ }^{(1)}$ Fried's model of defining fragile individuals has been praised for reproducibility and clinical consistency and has been validated despite negative results from large population studies. This index based on physical parameters evaluates only one aspect of frailty, while frailty is probably a complex, multidimensional concept $t^{(2)}$. Therefore, new strategies for identifying and assessing frailty in the elderly are needed. The use of biomarkers as new methods for diagnosing frailty could ensure greater accuracy in the detection of fragile subjects in the early stages ${ }^{(3)}$.

The aim of the paper was to evaluate the role of biomarkers in identifying people at high risk of frailty. The results of studies on biomarkers used to assess fragility were evaluated from the PubMed and Cochrane databases.
\end{abstract}

Conclusion. It is considered that biomarkers may be useful for the management of fragile patients only in combination with several biomarkers or with a clinical marker.

Keywords: frailty syndrome, biomarkers, frailty index, elderly.

\section{Rezumat}

Fragilitatea este un concept important în medicina geriatrică și studierea etiologiei sale a devenit o aspirație fundamentală a multor cercetători în domeniul îmbătrânirii( ${ }^{(1)}$. Modelul lui Fried de definire a persoanelor fragile a fost lăudat pentru reproductibilitate și coerență clinică și a fost validat în pofida rezultatelor negative din studiile populaționale mari. Acest indice, bazat pe parametrii fizici, evaluează doar unul dintre aspectele fragilității, în timp ce fragilitatea este, probabil, un concept complex, multidimensional ${ }^{(2)}$. Prin urmare, sunt necesare noi strategii de identificare și evaluare a fragilității la vârstnici. Folosirea biomarkerilor ca metode noi pentru diagnosticarea fragilității ar putea asigura o mai mare precizie în detectarea subiecților fragili în stadii timpurii( ${ }^{(3)}$. 


\section{INTERNAL}

\section{General Reviews}

Scopul lucrarii a fost de a evalua rolul biomarkerilor în identificarea persoanelor cu risc crescut de fragilitate. Au fost evaluate rezultatele studiilor privitoar la biomarkerii utilizați în evaluarea fragilității din bazele de date PubMed și Cochrane.

Concluzie. Se consideră că biomarkerii pot fi utili pentru managementul pacienţilor fragili doar în combinație de mai mulți biomarkeri sau cu un marker clinic.

Cuvinte-cheie: sindrom de fragilitate, biomarkeri, indice de fragilitate, vârstnic.

Elderly frailty is a complex syndrome characterized by vulnerability to stressors and decreased physiological reserve, which affects multiple organs and leads to decreased ability to perform normal daily activities, resulting in a progressive physiological decline in various systems and organs. This syndrome is associated with increased risk of falls and fractures, decreased quality of life, institutionalization, hospitalization, all of which contribute to increased mortality ${ }^{(4)}$.

Globally, frailty can affect anyone at all stages of life, with a prevalence rate from $4 \%$ to $59.1 \%$ depending on different demographics or socio-economic conditions. However, the main age group affected is the elderly (65 years and older) ${ }^{(5)}$. The systematic review conducted in 2012 by Dutch researcher Collar R.M., on the prevalence of fragility, showed that $10.7 \%$ of adults over the age of 65 years are more fragile, this percentage increases up to $15.7 \%$ and $26.1 \%$ respectively, for persons aged $80-84$ and over $85^{(6)}$.

Another randomized study conducted in 2017 by Italian researcher Liotta G. on the prevalence of frailty and its determinants, which used the geriatric evaluation questionnaire in the general population, revealed that $14 \%$ of fragile people and $7.6 \%$ of very fragile people are adults over the age of $65^{(7)}$.

The prevalence of frailty varies over time depending on changes in people's socioeconomic and physical conditions. Therefore, the syndrome is commonly known as a relative condition, without a well-defined threshold $^{(8)}$. Many factors in different areas, such as physical, social, psychological, sensory and cognitive states, can cause the frailty syndrome ${ }^{(9)}$. Although the theoretical foundations of the frailty syndrome are well established in the literature, its translation 
into practice, especially in everyday clinical life, remains controversial ${ }^{(10)}$. For this reason, many tools have been developed over the years to identify, measure and assess frailty. At this time, there are a multitude of tools, with extreme internal variability in terms of score, instructions and areas assessed ${ }^{(11)}$. From the wide range of tools used to assess frailty, the phenotype of frailty proposed by Fried L.P. in $2001^{(12)}$ and the frailty index (FI) studied and validated by Canadian researchers Rockwood K. and Mitnitski, A., are probably the best known ${ }^{(13)}$.

Some studies in the field also report some limitations of the use of these indices in the activity of medical practitioners although thesetwo methods are the most used in the evaluation of fragility. Canadian researcher Howlett S.E. and colleagues (2014), in their paper on the evaluation of standard instrumental and laboratory tests for the identification of elderly people at high risk of mortality, showed that the frailty phenotype does not allow to differentiate the frailty degree of severity, but only the ratio between the pathologies present in an individual and the total number of pathologies evaluated ${ }^{(14)}$. It is worth mentioning that these findings were estimated by the German scientist Ritt M., in 2017, who found that, although the frailty phenotype proved to be a very strong predictor in identifying people elderly people with an increased risk of mortality, the application of this index to evaluate the multiple pathologies present in patients requires a longer period of time ${ }^{(15)}$.

All of the above impose the need to implement more complex frailty assessment tools. Thus, it was proposed to use biomarkers as new methods for diagnosing frailty because they could ensure greater accuracy in the detection of fragile subjects. There are currently no standardized tests, biomarkers or parameters that can be used to diagnose patient frailty, which is why identifying frailty biomarkers is a major goal for future studies in the field.

\section{Aim}

The aim of the paper was to evaluate the role of biomarkers in identifying people at high risk of frailty.

In order to achieve the stated goal, the results the of the studies on biomarkers used in frailty assessment, from PubMed and Cochrane databases, were assessed. The information was systematized, highlighting the main aspects of the contemporary vision on biomarkers in the management of the frailty syndrome.

\section{Results}

Several biomarkers are currently used for the diagnosis, prognosis and stratification of the frailty syndrome. The predictive value of these biomarkers in the frailty syndrome has not yet been systematically examined. Experts note that the use of a single biomarker is not sufficient to assess frailty, suggesting that a combination of biomarkers or an association between biomarkers and clinical indices of frailty is needed ${ }^{(16)}$.

Regarding the prognostic value of frailty biomarkers, the study conducted in 2015 by Canadian scientist Mitniski A., who examined a laboratory frailty index based on 40 biomarkers, demonstrated that the joint use of $\mathrm{FI}$ and Fried's frailty phenotype with biomarkers have a higher degree of mortality prognosis compared to the use of only physical indices ${ }^{(3)}$.

These findings were previously estimated in the aforementioned study of Canadian researchers Howlett S.E. and Rockwood M.E. 


\section{INTERNAI}

\section{General Reviews}

(2014), where the evaluation of 21 biomarkers in combination with the measurement of systolic and diastolic blood pressure in the elderly showed that a frailty index based on laboratory data can identify elderly people with high risk of mortality ${ }^{(14)}$.

Biomarkers that play a specific role in the context of frailty syndrome are considered to be related to anaemia, vitamin deficiency, but also inflammatory markers.

About a third of elderly people with anaemia are iron deficient, another third are people with kidney failure or chronic inflammation as a cause of anaemia. The term "anaemia of unknown etiology" is also employed in the literature, being used when investigations are unable to suggest the cause of anaemia. The INCHIANTI study, conducted by a group of American researchers who studied anaemia in the elderly, showed that haemoglobin levels are closely correlated with reduced physical performance and low muscle strength, characteristic of the elderly ${ }^{(17)}$.

In another more recent study published by Gowanlock Z. in 2016, it was shown that low erythropoietin levels in the elderly play a key role in the pathogenesis of anaemia of unknown etiology ${ }^{(18)}$.

Another laboratory indicator of frailty is the deficiency of vitamins (vit. B, vit. D). The association between vitamin $D$ deficiency and osteoarticular pathology is well known, but in recent years there has been evidence of its role in the metabolism of a wide variety of cells ${ }^{(16)}$, as well. Proximal muscle weakness, reduced muscle strength, as well as an increased rate of falls are attributed to vitamin $D$ deficiency. Falls are a major problem for people over 65 years old, leading to significant morbidity, increased mortality and substantial resource consumption. The meta-analysis of American researcher Murad M.H. (2011), which included 26 observational studies, selected based on empirical evidence and clinical reasons, reported that vitamin $\mathrm{D}$ combined with calcium reduces the risk of falls in the elderly ${ }^{(19)}$.

These data were further challenged by the Spanish scientist Scheel F. who, in 2016, published the results of his study regarding the importance of vitamin D in the prevention of falls, showing that the use ofvitamin $D$ does not alter the risk of falls in the elderly (20). Thus, the role of vitamin D in the frailty syndrome is not fully elucidated, extensive randomized studies being needed.

The link between inflammation and frailty is a topic of interest due to the associated multiple pathogenic effects. Thus, in recent years, the central role of chronic inflammation in the pathogenesis of frailty is highlighted $^{(21)}$. Among the inflammatory markers that accompany the aging process and the age-related pathology, proinflammatory cytokines: interleukin-6 (IL-6), 
tumour necrosis factor alpha (TNF- $\alpha$ ) and its soluble receptors STNF-RI, STNF-RII and proteins of acute phase: C-reactive protein (CRP), fibrinogen, neutrophils, erythrocyte sedimentation rate (ESR) seem to have a special role in assessing frailty ${ }^{(22)}$.

The study by English researcher Hubbard R.E., published in 2013, which included a number of 110 patients with frailty, provided additional data on the link between chronic inflammation and frailty in the elderly. The research results showed for $\mathrm{FI}$ a significant correlation, directly proportional with CRP, IL6 and TNF- $\alpha$ and inversely proportional to albumin ${ }^{(23)}$.

The same data were found in the work of Spanish researcher Marcos-Perez M. and his collaborators (2018), which confirmed the involvement of chronic inflammation in the frailty status in the elderly population, with a particularly strong association proved between IL- 6 and sTNF-RII. The data obtained for STNF-RII indicated higher accuracy for the predictive value of this frailty biomarker ${ }^{(24)}$.

\section{Conclusion}

Although the possible use of laboratory biomarkers in the assessment of frailty has generally been established, these have not yet been accepted as diagnostic tools. Studies in the field have reported that the use of a single biomarker has no prognostic or diagnostic value for frailty, a combination of several biomarkers or with a clinical marker being necessary.

\section{Conflicts of interest}

The authors declare no conflicts of interest

\section{References}

1. Wu C., Smit E., Xue Q.L., et al. Prevalence and Correlates of Frailty Among Community-Dwelling Chinese Older Adults: The China Health and Retirement
Longitudinal Study, J Gerontol A Biol Sci Med Sci.,2017 Dec 12;73(1):102-108. doi: 10.1093/gerona/glx098.

2. Banded-Roche K., Seplaki C.L., Huang J., et al. Frailty in older adults: a nationally representative profile in the United States, J Gerontol A Biol Sci Med Sci., 2015;70:1427-1434. doi:10.1093/gerona/glv133.

3. Mitnitski A., Collerton J., Martin-Ruiz C., et al. Agerelated frailty and its association with biological markers of ageing, BMC Med, 2015; 13: 161.

4. Clegg A., Young J., Iliffe S., et al. Frailty in elderly people, Lancet, 2013;381:752-762. doi:10.1016/S01406736(12)62167-9.

5. Buckinx F., Rolland Y., Reginster J.Y., et al. Burden of frailty in the elderly population: perspectives for a public health challenge, Arch Public Health, 2015; 73(1): 19. doi: 10.1186/s13690-015-0068-x

6. Collard R.M., Boter H., Schoevers R.A., et al. Prevalence of frailty in community dwelling older persons: a systematic review, J Am Geriatr Soc., 2012; 60(8): 1487-92.

7. Liotta G., O'Caoimh R., Gilardi F., et al. Assessment of frailty in community-dwelling older adults residents in the Lazio region (Italy): A model to plan regional community-based services, Arch Gerontol Geriatr, 2017 Jan - Feb;68:1-7. doi: 10.1016/j.archger.2016.08.004.

8. Gilardi F., Capanna A., Ferraro M., et al. Frailty screening and assessment tools: a review of characteristics and use in Public Health, Annali di Igiene : Medicina Preventiva e di Comunita, 2018, 30(2):128139DOI: 10.7416/ai.2018.2204 PMID: 29465150.

9. Labra C., Maseda A., Lorenzo-López L., et al. Social factors and quality of life aspects on frailty syndrome in community-dwelling older adults: the VERISAÚDE study, BMC Geriatr., 2018 Mar 7;18(1):66. doi: 10.1186/s12877018-0757-8.

10. Clegg A., Tineri J., Iliffe S., et al. Frailty in elderly people. Lancet. 2013 Mar 2;381(9868):752-62. doi: 10.1016/S0140-6736(12)62167-9.

11. Cesari M., Gambassi G., Abellan van Kan G., et al. The frailty phenotype and the frailty index: different instruments for different purposes, Age Ageing. 2014 Jan;43(1):10-2. doi: 10.1093/ageing/aft160.

12. Fried L.P., Tangen C.M., Walston J., et al. Frailty in older adults: evidence for a phenotype, J Gerontol A Biol Sci Med Sci., 2001;56:M146-M156.

13. Rockwood K., Mitnitski A. Frailty defined by deficit accumulation and geriatric medicine defined by frailty, Clin Geriatr Med., 2011;27:17-26.

14. Howlett S.E., Rockwood M.R., Mitnitski A., et al. Standard laboratory tests to identify older adults at increased risk of death, BMCMed., 2014;12:171.

15. Ritt M., Ritt J.I., Sieber C.C., et al. Comparing the predictive accuracy of frailty, comorbidity, and disability for mortality: a 1-year follow-up in patients hospitalized 
General Reviews

in geriatric wards, Clin Interv Aging, 2017;12:293-304.

16. Pena M.C. Rolul parametrilor de laborator în predicția, identificarea și monitorizarea fragilității vârstnicului, Medical Market Geriatrie, 2018, vol.2018,p.18.

17. Cesari M., Penninx B.W., Lauretani F.J., et al. Hemoglobin levels and skeletal muscle: results from the InCHIANTI study, J Gerontol A Biol Sci Med Sci., 2004 Mar;59(3):249-54.

18. Gowanlock Z., Sriram S. , Martin A., et al. Erythropoietin Levels in Elderly Patients with Anemia of Unknown Etiology, PLoSOne. 2016; 11(6): e0157279.

19. Murad M.H., Elamin K.B., Alkatib A.A., et al. The Effect of Vitamin $D$ on Falls: A Systematic Review and Meta-Analysis, 2011 Oct;96(10):2997-3006. doi: 10.1210/jc.2011-1193.

20. Scheel F., Carrasco M. Is vitamin D supplementation effective for the prevention of falls in elderly people, Medwave, 2016 Jan 26;16 Suppl 1:e6368. doi: 10.5867/medwave.2015.6368.

21. Singh T., Newman A.B., Inflammatory markers in population studies of aging, Ageing Res Rev., 2011; 10: 319-329.

22. Varadhan R., Yao W., Matteini A., et al. Biologically Informed Inflammatory Index of Two Serum Cytokines Predicts 10 Year All-Cause Mortality in Older Adults, J Gerontol A Biol Sci Med Sci, 2014 Feb; 69A(2): 165-173.. doi: 10.1093/gerona/glt023.

23. Hubbard R.E., O'Mahony M.S., Savva G.M., et al. Inflammation and frailty measures in older people, J Cell Mol Med, 2009;13:3103-9. doi: 10.1111/j.15824934.2009.00733.x.

24. Marcos-Pérez D., Sánchez-Flores M., Maseda A., et al. Frailty in Older Adults Is Associated With Plasma Concentrations of Inflammatory Mediators but Not With Lymphocyte Subpopulations, Front Immunol, 2018; 9: 1056. doi: 10.3389/fimmu.2018.01056. 